\title{
Intraductal Lesion
}

National Cancer Institute

\section{Source}

National Cancer Institute. Intraductal Lesion. NCI Thesaurus. Code C62214.

A morphologic finding indicating the presence of a benign, atypical, or malignant cellular proliferation within the ducts in a tissue sample. 